\title{
The Economic-Constitutional Principles in Public Private Partnerships in the Framework of Human Rights*
}

\author{
Ma. Enriqueta Mancilla Rendón\# \\ La Salle University, Degree in Law Adriana Daniela Sinta Rojas ${ }^{\dagger}$, National Autonomous University of Mexico \\ Email: maenriqueta.mancilla@ulsa.mx, adsrmosa@hotmail.com
}

Received 17 October 2015; accepted 18 December 2015; published 23 December 2015

Copyright (C) 2015 by author and Scientific Research Publishing Inc.

This work is licensed under the Creative Commons Attribution International License (CC BY).

http://creativecommons.org/licenses/by/4.0/

c) (i)

\section{Abstract}

In the last decade the federal government has developed projects with alternative mechanisms to the traditional way of financing in order to offer quality services and infrastructure that the traditional schemes could not provide in an efficient and timely manner. The aim of this paper is to analyze the coherence, consistency, ambivalence or ambiguity of the legal concept of Public Private Partnerships (PPP), from the legal logic of economic principles in constitutional law and the link with human rights, and transparency in public spending. Its main premise is that the State has an obligation to guarantee fundamental rights. It is a descriptive study of transactional cutting with legislative methodology. As a result of the study it is important to understand that a new analysis of the Public Private Partnership Act is necessary to learn about its effectiveness, or if appropriate, to determine the State's obligation when making Public Private contracts with economic entities that do not comply with the social order, acting in detriment of the citizens.

\section{Keywords}

PPP, Economic-Constitutional Principles, Public Private Partnership Act

\footnotetext{
*The study is a product derived research project "Study of governmental accounting" key CA/012/15. The work made in the field theory of contributions, the Master of Laws, FES Acatlán, UNAM.

"PhD from the UNAM. Researcher at the Universidad La Salle. Group Leader Research, Development and Innovation: "Study of regulation, tax, financial and audit” of La Salle University; Member of the National System of Researchers Level 1CONACYT; Member of the Mexican Institute of Accountants public;Professor of Law Postgraduate Course, FES Acatlán, UNAM. Mexico.

${ }^{\dagger}$ Degree in Law from the UNAM. Student of the Master of Law Graduate Law (National Quality Graduate Program, CONACYT), FES Acatlán, UNAM.
} 


\section{Introduction}

The first topic is the duty of the state to prevent, investigate, prosecute, punish and remedy violations committed, duties set forth in Article I of the Constitution of the Mexican United States, third paragraph states "All authorities in the scope of their competence, have the obligation to promote, respect, protect and guarantee human rights in accordance with the principles of universality, interdependence, indivisibility and progressiveness. Consequently, the State must prevent, investigate, punish and remedy violations to human rights, in the terms established by law".

In this regard, Abramovich and Courtis [1] point out "four levels of obligations may be discerned: obligations to respect, protect, ensure and promote; obligations to respect are defined by the power of the State not to interfere with, hinder or prevent access to the enjoyment of the goods that are the subject of law; obligations to protect consist of preventing others from interfering, hindering or impeding access to these goods; obligations to ensure that the entitled holder has access to the good when he cannot do it himself. Obligations to promote are characterized as the duty to develop the conditions for the entitled persons to have access to the good". According to the authors [2], the above theoretical framework vindicates and "reinforces the unity of civil and political rights and the economic, social and cultural rights, as the different types of state obligations can be found in both rights".

According to the above classification, the obligations with immediate effect and obligations of progressive compliance are also mentioned, and it is noted that civil rights are immediately applicable while social rights are subordinated to the availability of resources, that is why they must be progressively developed, to which the Inter-American Institute of Human rights [3] notes "wrong posture, since social rights involve immediate obligations in some areas, such as non-discrimination and the adoption of measures for their realization".

\section{Contextual Framework of Public-Private Partnership}

The provision of basic infrastructure, significantly contributes to greater social welfare and a better quality of life. Therefore, one of the most important challenges faced by all governments is precisely to develop more and better basic infrastructure in the different areas that the society demands, health, housing, water, energy, communications, transportation, public safety and education ${ }^{1}$. And yet, he adds "at the global and regional context, characterized by strong recessionary economies where fiscal adjustment policies and fiscal consolidation are applied, the budget and financial resources in the public sector are insufficient to meet the demand for investment to develop basic infrastructure, these new contracting schemes, participation or alliances are known by the generic name of associations or public-private partnerships (PPP)", whose aim is, according to the referred report, to direct public resources towards the essential functions of public administration.

Whenever the Final Report of the Program for the Promotion of Public-Private Partnerships in Mexican States [5], which if it is true, serves as an introductory and foundation for the study of the PPPs, it is an instrument not binding for the Mexican State, so is, that this is an argument of authority properly supported, for containing qualified and genuinely independent sources, even more, the source complies with the principle of the scientific nature of law, that is, are verifiable, result of the above, are the manifestations and conclusions to which it reaches.

It is the main reason why emphasis is given at the beginning of the scientific nature of the right, since the arguments of authority rightly point a factual situation, Carrillo de la Rosa [6], that is, management of public resources performed the essential functions of Public Administration, which implies an inefficiency of the traditional model of management of public infrastructure, but the same report also notes provision of services, that is, the report in question implicitly (BID) notes that all that infrastructure, comprises functions and services, which requires to be differentiated from now on, since Trevino [7] describes "the establishment of a contractual longterm relationship between the public sector and the private sector based on mutual trust and equity in the relationship" to the function that as a State "is obliged to provide", task to be performed by this institution, and that the legal Thematic Dictionary [8] defines as "a fulfillment of something of a duty".

The service is, according to the Royal Spanish Academy "the Activity carried out by the Administration or,

\footnotetext{
${ }^{1}$ The International Monetary Fund (2007) [4] describes a Public Private Partnership (PPP) as the arrangements under which the private sector supplies infrastructure assets and services traditionally provided by the State. PPPs can be established through concessions and operating leases and can be created for social and economic infrastructure projects such as roads, bridges and tunnels, and "housing" such as hospitals, schools and prisons.
} 
under some control and regulation of this by an organization, specialized or not, and designed to meet needs of the community"; in the same way that the legal Thematic Dictionaries (2000) describe the services as "means that the society uses to meet that need, which consist of the organization created by the State, or, in the granting that is given to individuals so that they carry it out, of course, under the control and surveillance of it”, definitions that now make clear, the depth they pose to the subject of study, and given the importance they have, must not be treated interchangeably by the report in question.

For Trevino (2014) the common denominator in the term PPP is the existence of one or more entities that represent the interests of the State, which are called "public entity" and the presence of one or more entities of private or social sectors to which we can call conceptually as "private entity”. Which are the subjects of a PPP, which cannot exist without the coexistence of both subjects? In this order of ideas, on January 162012 the President of the Republic at that time, enacts the Public Private Partnership Act, which in the first article indicates "This Law is promulgated public order and seeks to regulate the schemes for the development of projects of public- private partnerships, under the principles of Articles 25 and 134 of the Constitution of the United Mexican States”.

Article 25 referred relates to the guidance of the development, whose first paragraph notes that the State has the rectory of national development to ensure that it is comprehensive and sustainable, to strengthen the sovereignty of the nation and its democratic regime and that through competitiveness, promotes economic growth and employment and a fairer distribution of income and wealth, allows the full exercise of the freedom and dignity of individuals, groups and social classes, whose security is protected by this Constitution. The public, social and private sectors will contribute, with social responsibility, without prejudice to other forms of economic activity that contribute to the development of the Nation. Under criteria of social equity, productivity and sustainability, enterprises of the social and private sectors of the economy will be supported and encouraged, subjecting them to the procedures dictated by the public interest and to the use, in general benefit, of productive resources, guarding their conservation and the environment.

The current constitution is not an axiological homogeneous unitary document, but there is a pluralism made up by criteria taking into account the verifiability of the normative reference against empirical reference (Carrillo de la Rosa, 2010), which are contradictory or with the tendency to be contradictory, characteristic of the scientific nature of law.

In this order of ideas, constitutions must be recipients of various values making them coexist in holistic synergy and constructive cooperation as proposed by Zagrebelsky (1997) [9] "the need for a legal doctrine liquid or fluid [...], the constitutional dogmatic must be as liquid where the substances that are poured - the concepts preserve their individuality and coexist without restrictive crashes, but with certain oscillating movements, and in any case, without that a single component may be imposed or eliminate others [...] the only solid content is the plurality of values and principles”.

Likewise, Article 134 of the Constitution states “economic resources, management and tenders”, which, to the letter says in its first paragraph: "The economic resources available to the federation, states, municipalities, the Federal District and the political-administrative organs of their territorial boundaries, will be managed with efficiency, effectiveness, economy, transparency and honesty to fulfill the purposes for which they are intended".

Due to the above, it is reflected as Jean Claude Tron Petit calls it [10] a sustainable culture requires a holistic and interdisciplinary philosophy, that is, the principles under which the PPPs are governed, are represented as follows: efficiency, security, sustainable development, dignity, wellness, freedom, fair distribution of wealth, and transparency.

In this regard, Zagrebelsky (1997) notes "in the application of the principles when reality demands of us a reaction, to adopt an attitude about it in accordance to them”. Meanwhile, Robert Alexy (1993) [11] who defines them "as mandates of optimization, are regulations ordering something to be done as much as possible, within the existing legal and real possibilities”. On the other hand, we find the guideline that Ronald Dworkin (2002) [12] accurately defines as "the kind of standard that proposes a goal that must be achieved; usually an improvement in some economic, political, or social feature of the community (though some goals are negative, in terms that stipulate that a current feature must be protected from adverse changes). And he continues: I call principle a standard that must be observed, not because it favors or ensures a social economic, political situation, deemed desirable, but because it is a requirement of justice, equity, or some dimension of morality”.

In this order of ideas, Article 1 of the Law on Public Private Partnerships is interpreted in a systematic manner consistent with the principles contained in Articles 25 and 134 of the Constitution of the United Mexican States, 
serving the Law on Public Private Partnerships as a programmatic norm or policy of action to achieve certain purposes, and thus make real certain projects, which in most cases as in the report abovementioned, are peculiar and very unusual in the case of economic, social and cultural rights, however, we must not fail to note the argument of enforceability and uniqueness of the rights either first, second or third generation, and its systematic interpretation with constitutional Article 1 third paragraph.

In this regard, Jean Claude Tron Petit refers "a weakness is characterized by [...] action policies, are not specific regulators of specific behaviors", example of this is the Public Private Partnership Act, which in its second article indicates public-private partnership projects regulated by this Act are those that occur under any scheme to establish a long-term contractual relationship between public and private sector entities, for the provision of services to the public sector, wholesalers, intermediate or the final consumer, and in which all or part of provided infrastructure is used by the private sector with the aims to increase social welfare and investment levels in the country. Under the terms provided in this Act, public-private partnership projects must be fully justified, specify the social benefit to be obtained and demonstrate its financial advantage over other forms of financing.

Therefore, according to the BID in the report "the term covers a large variety of schemes that can be carried out through public service concessions, public infrastructure concessions, turnkey construction contracts, construction-lease-transfer contracts, building-operational contracts, design-building-financing operation contracts, contracts for the sale and purchase of capacity and electricity, public companies with private participation, private companies with public participation, contracts of association or participation agreements and contracts to provide long-term comprehensive services, among many others”, even the International Monetary Fund recognizes the lack of uniformity of opinion as to what is and what is not a PPP and cites a definition of the European Commission that notes "the transfer to the private sector of investment projects that traditionally have been executed or financed by the public sector". However, the author notes that two important characteristics are presented: a. greater emphasis on service delivery and financing by the private sector; b. significant risk transfer to the private sector ${ }^{2}$.

In this sense, the Law notes in Article 14 a sublime writing regarding the feasibility of the proposed publicprivate partnership, which will not be transcribed in full, and notes: IV. The legal feasibility of the project; VI. The social profitability of the project; VII. Estimates of investment and contributions in cash and in kind, both federal and private and, where appropriate, state and municipal; VIII. The economic and financial viability of the project; IX. The convenience of carrying out the project through a system of public-private partnership, which includes an analysis on other options.

The Secretariat of Finance and Public Credit (2015) [14] will coordinate and publish a register for statistical purposes with the information relating to projects of public-private partnership, as well as a) Name of the project; b) Number of bids and/or registration of CompraNet government electronic public information system; c) Name of convener; d) Name of the developer; e) Contract term of public-private partnership; f) Total amount of the project; g) Amount of payments scheduled and executed during the project life cycle; h) Indicators associated with the social, financial and economic profitability of the project; i) Results of the evaluation of convenience; j) Other information that the Secretariat of Finance and Public Credit considers relevant.

The information will be of public nature, except that of privileged or confidential, in accordance with the Federal Law of Transparency and Access to Public Government Information and other applicable nature. It is also an obligation of the Secretariat of Finance and Public Credit, to present the draft Budget of Expenditure of the Federation and include an assessment of the impact of projects of public-private partnership in public finances $^{3}$ during their life cycle.

To extend the meaning of the idea of the structure of the rules, we have Jean Claude TronPetit's appreciations, who points out the following:

Factual situation: the requirements or hypotheses set forth in the rule whose realization is made dependent the production of legal effects.

\footnotetext{
${ }^{2}$ According to Vasallo and Izquierdo (2010) [13] there are "two major drawbacks" that are often attributed to PPPs are: Transaction costs are much higher than a conventional procedure of provision of infrastructure. The financial cost is much higher in a PPP than in the event that the project is financed with public debt".

${ }^{3}$ The Expenditure Budget of the Federation 2015 foresees a social spending for the project to replace the General Hospital "Dr. Gonzalo Castañeda Escobar”, through the figure of Public Private Partnership (SHCP, 2013) [15]. The capital expenditure will be 1613.1 million pesos, of which 1026.4 are for the construction and operation of the new hospital and the construction of a new Clinical Hospital in Merida, Yucatan whose budget value is 586.7 million pesos. There is no evidence of other PPP projects that have been carried out as Regional High Specialty Hospitals in Mexico (BID, 2015) [16], (2014) [17].
} 
Ought to be: is the logical link between the factual conditions and the legal consequence.

Legal consequence: contains legal assumptions resulting of the valuation made by the legislator against other legal assumptions contained in the factual assumption of the norm.

In this order of ideas, the deontic contents of the last two paragraphs of Article 14, is a legal mandate to carry out certain conduct consisting of an action to present by the Secretariat of Finance and Public Credit the draft Budget of Expenditures of the Federation including impact assessment of public-private partnership projects on public finances, whereas in reality it does not happen, since none of the budgets of expenditures, nor budget projects release this kind of information, which implies that all related information is reserved.

\section{Study Legislative Methodology}

This is a descriptive study with a correlational scope describing the figure of the Public Private Partnership (PPP) of transactional character Hernández, Fernández and Baptista (2006) [18]. The analysis is performed in three stages. In the first stage of the investigation a document information search is performed. A theoretical, legislative contextual study of Public Private Partnerships is identified, capturing information contained in the constitution, laws, codes, regulations, and theorists who have developed the theme of the PPPs from the legal approach Ponce de León(2013) [19]. In the second stage of the research the information was captured using the hemerographic research technique and legislative reference notes, all under the interpretive frame of reference of dialogic and critical hermeneutics Álvarez (2003) [20] to identify variables of study. The limitation of the study lies in the perspective of the subject from the economic, legal and constitutional approach, to the perception of human rights in the conclusion of a contract in Public Private Partnership, probably induce a biased judgment.

The research was conducted in the system of legal norms and principles, in the frame of the science of law and aimed at the systematic, coherence, consistency, ambivalence or ambiguity of the legal concept of Public Private Partnership (PPP), from the legal logic of the principles in economic and constitutional law and human rights, and the link to public spending and its legal environment, whose main premise is that the state has an obligation to guarantee fundamental rights in order to make justice and ensure legal certainty. In the third stage of research the outcome is taken as evidence of the application of PPPs figure in the prison system of the country.

\section{Results}

On October 2, 2012, a few months after entering into force the Law on Public-Private Partnership, one of eight penitentiaries with the figure of Public-Private Partnerships was built, under President, who stated that what needs to be done is to increase penitentiaries (the Economist, 2012) [21], recalling that it was precisely President who presented, in 2009, the project initiative to issue the Law for Public-private Partnerships (Trevino, 2014) the legislation which is a reality to date.

According to Morales (2012) [22], what is relevant is that the concessionaries are the companies Ingenieros Civiles Asociados (ICA), and GIA Constructora y Edificadora, S. A. de C.V., Promotora y Desarrolladora Mexicana (Prodemex); Homex, TradecoandArendal. Other prisons would be completed later, concession awarded to Copachisa, a subsidiary of Cementos Chihuahua, S.A. de C.V. and CIMSA. All of them built and are about to build prisons with capacity of about 2520 total spaces and will increase the current capacity of little more than 20,000 spaces. In this sense, the future of prisons was promising for the PPPs figure, without overlooking that security is a proper and exclusive function of the State as well as the operation of prisons, however, they will agree with these modalities under the operation of the private, under the supervision of the security authorities.

It is a fact, parallel to the entry into force of the Law on Public Private Partnerships, that nearly six months before, the constitutional reform in the field of human rights was enacted, however, it did not arise by spontaneous generation, as it was a result of the moment when Mexico was opened to international scrutiny on December 2000, when a technical cooperation agreement between the Office of the High Commissioner of the United Nations for Human Rights and the Government of Mexico (2002) was signed, which led to the first phase implemented during 2001 and consisted of training activities related to medical and forensic documentation of torture, as well as workshops for indigenous organizations on mechanisms for protection of indigenous people. On April 2002 the agreement for the realization of the second phase, whose priority, Kompass (2003) [23] aimed at the development of diagnostics on the situation of human rights in México, as well as the agreement of July 2002, setting up a Representation Office of the United Nations High Commissioner for Human 
Rights in México ${ }^{4}$.

In this order, the first Diagnosis on the situation of Human Rights was carried out, whose recommendations already struggled to a constitutional reform that was supposed to overcome and leave behind the conceptual debate on individual rights, fundamental rights and human rights. This diagnosis clearly established and justified the general principles of human rights, both those related to the fundamental freedoms (civil and political) as those that enabled an adequate standard of living for all people (economic, social and cultural), i.e. putting an end to the so-called generations of rights, and the programmability of the standards, pointing out principles that protect the integrity of the people who put limits on State power, which determine the State's obligations to promote the development of people in all areas. In that sense, the diagnosis stated regarding the prison system, the social rehabilitation must be conceived as a right, synonymous with service opportunities, work and study options, to be offered to all inmates and even those prosecuted people ${ }^{5}$.

According to the figures presented in the Third Report of Government, for the month of July, 2003 the National Penitentiary System reported an overpopulation of 27.9\%, 4.8 points higher than in December of two thousand and two ${ }^{6}$. However, the report warns the solution proposed by the federal government to abate overpopulation, based on the creation of new spaces, will not address the core problem: what is at issue here is to abate overpopulation by reducing the number of inmates and not increasing the spaces of confinement [...], should not be solved by legal forms that encourage overwhelming growth of the prison system, such as the administration of prisons with the legal concept of public-private partnership.

The paragraph 2.1.3.10 regarding the particularities of women in prison situation, states that there is no certainty as to show the situation of women in prison (Kompass, 2003), "despite the constant between observed problems is the lack of a focus on gender in the prison system [...], unequal application of different instruments, both legal and administrative, and discriminatory practices in access to defense and legal representation by women, among other situations [...], no separation between men and women is respected [...], confinement of children of women prisoners since they are separated from their mothers at an early age and when the stay of children inside the centers is permitted, there are no conditions, activities or staff”.

Another significant moment took place with the proposal of the Constitutional Reform on Human Rights prepared by the Civil Society Organizations and various academic specialists on Human Rights (2008) [24]. The proposal was structured based on a set of strategic issues in order to achieve six major objectives:

1. Fully introduce the concept of human rights in the Mexican Constitution;

2. Ensure the highest hierarchy and regulatory efficacy of international instruments on Human Rights within the Mexican legal system;

3. Explicitly introduce some human rights that have not been recognized in the Constitution so far;

4. Strengthen the protection of some human rights already recognized by the Constitution in the light of the International law on Human Rights;

5. Introduce the gender perspective in the way that the constitution recognizes and protects human rights;

6. Strengthen the guarantees and protection mechanisms for human rights;

Four years later, the constitutional reform was passed and published in the Official Journal on June 10, 2011,

\footnotetext{
${ }^{4}$ According to Kompass (2003) the general scope of the assessment considered 1. Amend the Constitution to incorporate the concept of human rights as a fundamental axis of it. 2. Enact laws that human rights are constitutionally recognized and to ensure their protection from the federal and local governments. 3. Include in the constitutional procedures for appointing senior public servants transparency mechanisms that allow society to provide evidence as to the suitability of the persons proposed. 4. Develop mechanisms for intervention of federal authorities in the states to violations of human rights attributable to local authorities. 5. Grant autonomy to all public human rights commissions. 6. Ensure consultation methods to society in the selection of those who lead and participate in citizens' advice and promote transparency and accountability of all government agencies that depend on the Executive and have powers in the field of human rights. 7. Define a program that includes protection to their role of defenders of human rights. 8. Promote human rights, particularly for vulnerable people. 9. Eliminate discriminatory practices in public services. 10. Periodically publish the progress in meeting the recommendations made by national and international organizations and agencies, in the case of the disappearances in Cd. Juárez. 10. Line up human rights to justice system, public safety, other civil rights, about human rights of women, indigenous people, economic, social and cultural rights, on political rights. ${ }^{5}$ The Human Rights Committee of the United Nations noted that "persons deprived of liberty [...] may be subject to [...] hardship or constraint other than that resulting from the deprivation of liberty; respect for the dignity of persons under conditions applicable to free men conditions must be ensured. Persons deprived of their liberty enjoy all the rights [...], subject to the inevitable restrictions on prison conditions, [...] including the basic social rights that ensure detention compatible with human dignity (IIHR, 2008).

${ }^{6}$ “'The Mexican prison system is made up of 448 centers, of which 5 are dependent on the federal government ( 3 centers of maximum security penal colony and a center for psychosocial rehabilitation). As for the remaining 347 are administered by state governments, 8 by the Government of Mexico City and 88 by municipal authorities. [...] In July 2003 the prison population was 183.547 persons deprived of their liberty, of which 77.651 were under process and 105,896 were sentenced” (Kompass, 2003).
} 
including basis for The Penitentiary System organization, from now on, on the foundations of respect for human rights by pointing "The prison system is organized on the basis of respect for human rights, labor, training, education, health and sports as a means to achieve the reintegration of the convicted into society and to ensure that he will not commit a crime again , noting the benefits provided by law. Women will serve their terms separately from those places intended for men for this purpose".

On the other hand, the amendment to article 89, section X that describes the powers and duties of the President, conduction on foreign policy, observing respect and protection of human rights, a sensitive article, thus it considered a character of efficiency and effectiveness involving the public administration, particularly those State organs responsible for the promotion and defense of human rights such as the National Commission. The establishment of the obligation of public servants to respond to the recommendations of the National Human Rights Commission (CNDH), as if they do not fulfill them, they must ground and justify their refusal. In this context, and attentive to the powers conferred by the constitutional reform to the National Human Rights Commission, it issues Special Report of the National Commission of Human Rights on female inmates in the prisons of Mexico, in which it reiterates its "concern about the conditions and treatment to women who are deprived of liberty and children living with their mothers in confinement".

The transgression of the basic rights of these people, due to a series of irregularities regarding facilities, food, medical care, technical and security staff; labor, education, sports; overcrowding and overpopulation conditions; lack of separation between men and women; physical abuse; differences in the way of life in seclusion between the latter and men ${ }^{7}$, lack of access to equal conditions and facilities and services CNDH (2015) [26].

According to Escamilla (2012) [27], among the establishments visited, 15 are unique to women in the country (including 13 state and two federal), which are listed below: one of them is the Nogales Social Rehabilitation Center for Women, which in the year 2012, was alleged to be the CEFERESO of large scale and proportion both in territory and in operation, as well as cutting edge technology, which means a major achievement for the Mexican penitentiary system since it effectively depressurizes existing centers and facilitates the classification and segregation of inmates avoiding "criminal contamination", and nowadays this is one of the CEFERESOS with higher breaches of the rights of women, Crónica (2015) [28], specifically the ones related to their legal situation, dignified and secure stay, the protection of health, personal integrity, social bonding, order management , disciplinary measures as well as those belonging to other vulnerable groups.

a) Physical and psychological abuse;

b) Deficiency in the material conditions of detention centers;

c) Lack of areas or spaces for access to services and activities

d) Inequality in facilities for women

e) Nutritional deficiency

f) Overpopulation and overcrowding

These and many more infringements to human rights are perpetuated in women's rehabilitation centers, and the National Human Rights Commission (CNDH) has an obligation to promote and defend ${ }^{8}$, however, although it is true that a significant number of inmates are processed without judgment, and despite the existence of the presumption of innocence contained in Article 14 and 16 of the Constitution, it is also certain that they are in such prisons, subjected to all forms of infringement of their human rights, regardless of the constitutional reform. It should be emphasized that the recent establishment of penal institutions is built with the PPPs figure, and although it is to improve the conditions of prisons of traditional creation, it is certain that there are still infringements to human rights, especially for vulnerable groups, that is, women and their children living there.

There are other tragic points that are a cause the social disease that prevails in México, and it is the lack of transparency in economic resources, that is, the conclusion of the contract of PPPs generates an expense for the State and is barely read in the Expenditure Budget of the Federation ${ }^{9}$, as Article 14 of the Law on Public Private

\footnotetext{
7"Recommendation 1469 of the Parliamentary Assembly of the Council of Europe Member States are encouraged to avoid the use of imprisonment in the case of women mothers with children and little girls and boys and young people, in light of the negative effects of seclusion of mothers to their children” Supreme Court (2014) [25].

${ }^{8}$ Human rights bind the State, therefore, all the authorities have an obligation to respect, protect, promote and guarantee them in accordance with the principles of universality, interdependence, indivisibility and progressiveness. The State must prevent, investigate, punish and remedy violations of human rights" (ONU, 2008).

${ }^{9}$ According to the International Monetary Fund (2007), "while PPPs can ease fiscal constraints that limit investment in infrastructure, they can also be used to circumvent controls on spending and move public investment off budget and debt off balance government. When this happens, the State may have to bear most of the risk involved in PPPs and face considerable fiscal costs in the medium to long term”.
} 
Partnerships illusorily warns, as a specific category does not appear in the financial statement of the Expenditure Budget of the Federation ${ }^{10}$, accurate information on PPPs projects but that in which public investment appears on the topic of prisons.

\section{Conclusions}

It has been understood the constitutionalisation of the principles, that is, the constitutional jurisdiction as guarantee in accordance with the Constitution for the benefit of citizens, that is, the economy is no longer, from the amendment to the constitution, a remote fact from the rights of individuals. The constitution contains the primacy of the principle pro-individual principle by favoring at all the time people with the widest protection, it is close harmony with international principle of non-discrimination which has the purpose to override or undermine the rights and freedoms of individuals. And the most important aspect for further analysis of the law subject is to study on its effectiveness, or if applicable, on determine the State's obligation to make Public Private contracts with entities that are far from fulfilling the social order, acting with permission of the State itself to the detriment of citizens, and that result in the interpretation under laws made by the judge in the possibility of applying the most favorable to comply in the best way.

On the other hand, the Mexican institutional system for Public-Private Partnerships is highly fragmented; each sector and level of government is responsible for planning, implementing and supervising projects. There is not council at the ministerial level that oversees the entire system, specifically for management and application of public resources applied projects PPPs.

\section{References}

[1] Abramovich, V. and Courtis, C. (2003) Apuntes sobre la exigibilidad judicial de los derechos sociales. http://ecaths1.s3.amazonaws.com/derechoshumanoscomision1/1469176853.ABRAMOVICH_y_COURTIS_-_Apuntes sobre la exigibilidad judicial de los derechos sociales[1].pdf

[2] Abramovich, V. and Courtis, C. (2003) Hacia la exigibilidad de los derechos económicos, sociales y culturales. Estándares internacionales y criterios de aplicación ante los tribunales locales. Disponible en: http://www.miguelcarbonell.com/artman/uploads/1/Exigibilidad_de_los_DESC_-_Abramovich.pdf

[3] IIDH (2008) Protección Internacional de los Derechos Económicos, Sociales y Culturales. Sistema Universal y Sistema Interamericano, Instituto Interamericano de Derechos Humanos (IIDH), San José.

[4] FMI (2007) Inversión pública y asociaciones público-privadas. International MonetaryFund

[5] BID (2007) Programa para el impulso de Asociaciones Público Privadas en Estados Mexicanos (PIAPPEM). Memorando de donantes. Banco Interamericano de Desarrollo, México. http://idbdocs.iadb.org/wsdocs/getdocument.aspx?docnum=971515

[6] Carrillo de la Rosa, Y. (2010) Cientificidad en las ciencias jurídicas y sociales, Saber, Ciencia y Libertad, Colombia. v.5 fasc.2, Publicaciones Universidad Libre, Cartagena, 39-50.

[7] Treviño, F. (2014) La Nueva Ley de Asociaciones Público Privadas. Editorial Porrúa, México.

[8] Diccionarios Jurídicos Temáticos (2000) Derecho Administrativo, Tomo III. Segunda edición, Oxford.

[9] Zagrebelsky, G. (1997) El derecho dúctil. Ed. Trotta, Madrid.

[10] Ferrer, M.G., Zaldivar, E. and Lelo de Larrea, E., Coords. (2009) La Ciencia del Derecho Procesal Constitucional, t. IV. In: Jean Claude Tron, P., Ed., Principios en derecho económico constitucional, México, UNAM, Porrúa, 1045

[11] Alexy, R. (1993) Teoría de los Derechos Fundamentales. Centro de Estudios Constitucionales, Madrid.

[12] Dworkin, R. (2002) Los derechos en serio. Barcelona, Ariel.

[13] Vassallo Magro, J. and Izquierdo de Bartolomé, R. (2010) Infraestructura pública y participación privada: Conceptos y experiencias en América y España. Editor: CAF, p. 350.

[14] (2015) Criterios para la realización de proyectos mediante un esquema de asociación público-privada. Oficio No. 102-B-043 BIS/Oficio No. 801.1-019. Secretaria de Hacienda y Crédito Público, Subsecretaría de Egresos, México.

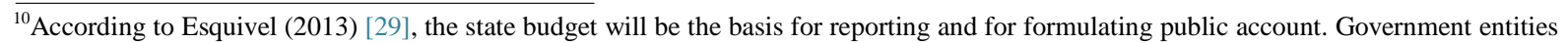
should prepare the financial statements in accordance with regulatory requirements and techniques issued by the National Council for Accounting Harmonization (CONAC) whose purpose is to ensure transparency and accountability in public spending. The implementation of government policy on real-time reporting should have been applied before December 31, 2012 and must have been carried out by entities accounting records of assets and their valuation. The 2015 federal whose budget financial information issues data with two PPP figures, Note three (SHCP, 2014, 2004) [30].
} 
[15] SHCP (2013) Proyecto para la Sustitución del Hospital General “Dr. Gonzalo Castañeda Escobar”, mediante un esquema de Asociación Público Privada. http://www.hacienda.gob.mx/EGRESOS/ppi/ProyectosAPP/i_descripcion.pdf

[16] BID (2015) ME-M1058: Estado de Chiapas: Impulso de Asociaciones Público-Privadas (PIAPPEM). Programa para el Impulso de Asociaciones Público-Privadas en Estados Mexicanos (PIAPPEM) ATN/MT-10287-ME. http://www.iadb.org/es/proyectos/project-information-age,1303.html?id=ME-M1058

[17] BID (2014) Evaluando el entorno para las asociaciones público-privadas en América Latina y el Caribe. Infrascopio 2014.

[18] Hernández, R., Fernández, C. and Baptista, P. (2006) Metodología de la Investigación. McGraw-Hill, México.

[19] Ponce de León, L. (2013) Metodología del Derecho. Ed. Porrúa, México.

[20] Álvarez, J.L. (2003) Cómo hacer investigación cualitativa, fundamentos y metodología. Paidós Educador, México, D.F.

[21] El Economista (2012) Estrenan primer Cefereso bajo esquema de APP. http://eleconomista.com.mx/sociedad/2012/10/02/estrenan-primer-cefereso-bajo-esquema-app

[22] Morales, M. (2012) Concesionan cárceles y propician mano de obra esclava. http://www.cronicadechihuahua.com/Concesionan-carceles-y-propician.html

[23] Kompass, A. (2003) Diagnóstico sobre la Situación de los Derechos Humanos en México. OACNUDH México.

[24] ONU (2008) Propuesta de reforma constitucional en materia de derechos humanos, elaborada por las organizaciones de la Sociedad Civil y por académicas y académicos especialistas en derechos humanos.

[25] SCJN (2014) Género y justicia, Ejecución penal y perspectiva de género. Boletín No. 58, Abril 2014.

[26] CNDH (2015) Informe Especial de la Comisión Nacional de los Derechos Humanos sobre las mujeres internas en los centros de reclusión de la República Mexicana, CNDH. http://www.cndh.org.mx/sites/all/doc/Informes/Especiales/2015_IE_MujeresInternas.pdf

[27] Escamilla, O. (2012) Nuevo CEFERESO en Hermosillo, Sonora. Notiley. http://notiley.com.mx/?p=1688

[28] Crónica (2015) CNDH: Maltrato, prostitución y autogobierno en penales femeniles. http://www.cronica.com.mx/notas/2015/891420.html

[29] Esquivel, M. (2013) Normas emitidas por el CONAC y su implementación. Contaduría Pública, Año 41, Núm. 491, 24-28. IMCP, México.

[30] SHCP (2004) ACUERDO por el que se establecen las Reglas para la realización de proyectos para prestación de servicios. Secretaria de Hacienda y Crédito Público, Diario Oficial de la Federación, viernes 9 de abril de 2004, s/pág. 